\title{
On the Professional Education of Social Sports
}

\author{
Jian Liu, Lijun Xu \\ Northeast DianLi University School of Physical Education, Jilin City, Jilin Province, China \\ 20009971@qq.com
}

\begin{abstract}
In order to satisfy the urgency of students, Entrepreneurship Education in higher education popularization is the inevitable result of social development, which is an important way to promote the sustainable development of social sports specialty. Therefore, the social sports specialty should reform the mode of talents training, which enhances personnel training goal, conforms to the requirements of the times, strengthens the education of starting an undertaking, in order to search for a good way for the implementation of entrepreneurship education, cultivation of talents with high quality in line with national construction demand.
\end{abstract}

Keywords- Entrepreneurship; Education of social sports; professional way

In the "Series of 2005 College Entrance Examinations Guide" written by the Ministry of education of University Education Department of education and employment , social sports specialty ranks the lower rate of professional employment, which has restricted the healthy development of social sports specialty and made it atrophic trend. Therefore, reforming the training mode, strengthening entrepreneurship education and broadening the field of culture are important ways to promote the sustainable development of social sports specialty.

\section{THE NECESSITY OF ENHANCING THE ENTREPRENEURSHIP} EDUCATION

A. To promote entrepreneurship education is the mission of higher education

The 17th CPC National Congress proposed "to promote the development of strategic entrepreneurship to employment". "Opinions" of the Ministry of education are to promote the innovation and entrepreneurship education in higher schools and students' independent venture work: "innovation and entrepreneurship education are suitable for all students to take part in the training process", "strengthening the construction of entrepreneurship education curriculum system innovation, which contains the innovation and entrepreneurship education in professional education and culture quality education and credit system teaching plan", "vigorously promote innovation and entrepreneurship education of colleges and universities". Therefore, about the higher education, we should implement the spirit of the instructions of the Central Party Committee, changing the education thought, renewing the education ideas, finishing the reform the training mode and the traditional talents in the period of planned economy ,which not only ensures the professional knowledge, skills and education, but also expands the field of entrepreneurship education, strengthens the direction of development and cultivates a "sense of social responsibility, the spirit of innovation, awareness and ability of starting an undertaking" in line with the national construction needs of high-quality personnel.

\section{B. $\quad$ The students' strong desire is in urgent need of entrepreneurship education}

A questionnaire survey was conducted about entrepreneurship education in social sports specialty in our college in two classes of 80 students: $97 \%$ of the students hope, hope very much, especially hope to be offered courses in entrepreneurship education; $98 \%$ of the students hope, hope very much, very much hope that they can learn the business knowledge at school; 94\% of the students have entrepreneurial aspirations; 91\% college students do not understand the country about entrepreneurship related encouragement policy; $38.9 \%$ of the students have entrepreneurial or business experience, of which 6 get the profits.

Student entrepreneurship related knowledge and learning during the period of school include the following: the basic steps of the business; the choices and entrepreneurship preparation, the business after the entrepreneurial orientation; the investment of basic knowledge and investment management; financing; enterprise management; economics; marketing; accounting; business operation; making and signed contract law; etiquette; entrepreneurship; examples; sports management. To cultivate the ability to get through entrepreneurship education are: the resisting ability of entrepreneurial risk, social skills, ability of interpersonal relationship and business skills. Education: the first is the business to make money, the way to take the property business can be a long time; the spirit of never yield in spite of reverses; courage; courage; sensitive judgment.

During the investigation of students, we were excited to have a talk with a teacher who was eager to get knowledge, skills, entrepreneurship education; who dislike the business, management experience with more profit than ideal. Have students found the home poker and poker spreading in our city can earn, go to shop or hotel to sell. Students have the intention to engage in "shoes" maintenance mechanization project, do the market survey in the school .

From the above survey data we can understand: our social sports professional students like entrepreneurship and entrepreneurial desire. They hope the relevant courses in 
entrepreneurship, expecting the related knowledge to learn entrepreneurship at the University of Business related knowledge the students who want to learn are very practical, pioneering the practical knowledge, including law, etiquette, etc.. The students also raises the entrepreneurial ability, the quality of education and "for the people", the "money, first for the people". The students think that college students "have the ideal, ambitious, bold, strong learning ability" and other advantages. The entrepreneurship can be "to alleviate the employment pressure, exercise self, self display, self realization of the value". The students all have a practical understanding of entrepreneurship.

Through the investigation and study, we painfully aware of the nation: "vigorously promote innovation and entrepreneurship education" in Colleges and universities today, our students have been at the front field of our education, our education has not realized its education function. We should change the education concept, with our professional social sports practice, by the way of reforming the teaching system, to improve the training of our scheme.

\section{Carry out the reform of the education mode, promote} professional development

The training mode of social sports specialty is based on the social sports knowledge and skill education, and talents training with the mass sports organization management, consulting, business development and scientific research and teaching skills. Looking on the whole is the existence of "cultivating innovation, light, light the tendency of employment". The direction of the main employment of social sports specialty in business fitness instructor are, limitation of instability, the development potential of this occupation, to enable students to the heart is exclusive, do not accord with the students' vision of the employment intention. The low employment rate, employment direction are not ideal, which causes the students of social sports become confused about graduation, lack of confidence in the professional training, lack of learning motivation, the development of the social sports professional challenge. Therefore, pattern must be changed the training of sports talents, and turning challenges into power, with professional knowledge, skills training while strengthening entrepreneurship education, entrepreneurship education system, should be the direction of the development of social sports specialty.

\section{REALIZATION OF ENTREPRENEURSHIP EDUCATION}

\section{A. Set optimizing curriculum}

"Entrepreneurship education" it is a cross discipline, which involves broad knowledge, and rich in content. Fusion of the philosophy, pedagogy, psychology, ethics, politics, economics, sociology, law and other disciplines of knowledge. Therefore, entrepreneurship education is complex, difficult, it also impedes the smooth implementation of entrepreneurship education. However, with many years of "entrepreneurship education" research, development, so far has shown a trend of independent discipline related to entrepreneurship education, entrepreneurship education "business management", ordinary university national planning materials have also been published, "Entrepreneurship education" has been integrated, concreted, setting up enterprise education, the course is simple. For the short-term training department, only students' entrepreneurship education organization is not enough, we must set up enterprise education courses, through the integrated teaching, learning business knowledge and skills, improve their competence. The contents of this course include theory and case. Through the successful case study, arouse students' enthusiasm and improve students' entrepreneurial firm confidence and undertaking faith.

\section{B. Set up "entrepreneurship education faculty"}

"Entrepreneurship education" is the product of the development times, it is a new discipline of education, teachers of the college entrepreneurship education foundation are weak, and there is no higher normal college to cultivate "entrepreneurship education" professional teachers. The current "entrepreneurship education" teachers are grown in self-study, exploration, practice in. In order to realize the development of entrepreneurship education must enhance the building of the contingent of teachers, improve the teaching level, ensure the quality of education. Thus we can improve the teachers' level through two channels: the training of teachers. Teacher training, learning, improve the level of theoretical knowledge in practice, at the same time, having the rich practice experiences. The external teacher hiring enterprise boss came into the classroom, implement the "school enterprise cooperation," the entrepreneurial education "true to life" more plump.

\section{The construction of practice base}

A lot of provinces, cities have built the "pioneering experimental incubator", "college students" and the establishment of 5000 female university students practice base in the country in 3 years". The school can use the social resources, the independent construction and social entrepreneurship experimental base combined, and joint enterprise, school, society, enterprise combination, build a "three-in-one" education mode. The school will offer support, material and financial resources on a good policy base. The policy is to ensure the students the quality of the professional learning and to offer a loose entrepreneurship policy. The financial resources are mainly to expand investment, entrepreneurship support, guarantee of students, to give facilities, equipment and other material support, assign the mentors including teachers and entrepreneurs and the common practice of students' entrepreneurial. The national social entrepreneurship bases encourage students to involve into practice base, participation, experience of entrepreneurship, provide support, and to encourage entrepreneurship policy guarantee. The enterprise from the 
reality, cases, teaching practice, help students analyze and solve practical problems encountered in the practice of entrepreneurship. Three joint efforts will be the ideal education effects.

\section{REFERENCES}

[1] The Jia Yan society sports specialized graduate social demand condition analysis and countermeasure study [2]Journal of Northeast Dianli University (SOCIAL SCIENCE EDITION) 2008.05 